\title{
The Forest Policies of ASEAN and Montréal Process: Comparing Highly and Weakly Formalized Regional Regimes
}

\author{
Sohui Jeon ${ }^{1}$, Pradip Kumar Sarker ${ }^{1,2,3, *}$ and Lukas Giessen ${ }^{3,4}$ \\ 1 Chair Group of Forest and Nature Conservation Policy, Georg-August University, Büsgenweg 3, \\ 37075 Göttingen, Germany; sohui0866@gmail.com \\ 2 Thünen Institute of International Forestry and Forest Economics, Leuschnerstrasse 91, \\ 21031 Hamburg, Germany \\ 3 European Forest Institute, Platz der Vereinten Nationen 7, 53113 Bonn, Germany; lukas.giessen@efi.int \\ 4 IPB, Bogor Agricultural University, Bogor 16680, West Java, Indonesia \\ * Correspondence: pradip.sarker@thuenen.de or psarker@gwdg.de; Tel.: +49-40-73962-338
}

Received: 26 March 2019; Accepted: 11 October 2019; Published: 21 October 2019

\begin{abstract}
Forests are governed by a combination of sub-national and national as well as global and regional regimes. Comparing the institutional variation of regional regimes, including their degrees of formalization, is gaining attention of studies on regionalism in International Relations. This study attempts to analyse the ways in which the selected cases of the forest-related Association of Southeast Asian Nations (ASEAN) and forest-focused Montréal Process (MP) regional regimes may have synergetic overlaps or disparity in their institutional design and forest policy development. For this, we combined IR's 'rational institutional design' theory and a policy analysis approach. Using a qualitative data approach, we analyzed key structure-related historical regime documents (e.g., charters) issued since the inception of both regimes, and their latest forest policy initiatives for the periods 2016-2025 (Strategic Plan of Action for ASEAN Cooperation on Forestry) and 2009-2015 (Conceptual Framework for the Montréal Process Strategic Action Plan) with all relevant policy documents since the adoption of current policies. Based on that, we pose the empirical questions of how both regimes illustrate governance structure (i.e., institutional design), and on the other hand how to explain regime forest policies coherently and consistently in terms of their high versus low degree of formality. The results show that institutional design is highly explanatory based on treaty and non-treaty regime formation as well as forest-related/focused regime formation with the synergistic sustainable forest management (SFM) issue that embraces deforestation and forest degradation, biodiversity, timber certification, and greenhouse gas emission. Additionally, the results suggest that the policy goals adopted by both regimes are coherent and consistent based on the full set of policy elements. Concerning the remedy for fragmented global forest governance arrangements, both regimes would be an example of practicing SFM-focused policies with the incorporation of forest-related policy elements into a larger governance assemblage dealing with issues such as biodiversity conservation or climate change mitigation.
\end{abstract}

Keywords: regional forest-related and forest-focused regimes; formalization; institutional design; forest policy development

\section{Introduction}

Forests are governed by a combination of sub-national and national as well as global and regional regimes. Policy analysis is mainly focused on international forest governance by global forest and forest-related regimes, e.g., on sustainable forest management [1-3], environmental issues 
such as biodiversity and climate change [4], trade, and other forest-related issues [5-9]. However, the international forest regime is described as multi-centric and fragmented due to the absence of a unifying legally binding agreement on world's forests [6,7]. Consequently, the international forest regime has lately been conceptualized as an international forest regime complex (IFRC) $[6,7,9,10]$. According to Keohane and Victor [11] (p. 3); [12] (p. 7), a regime complex "is a set of specialized sectoral and issue-based regimes and other governance arrangements that are more or less loosely linked together, sometimes mutually reinforcing but at other times overlapping and conflicting." The exceptionally high abundance of various international regimes addressing forests in multiple ways and the resulting fragmentation of the regime complex are due to the multiple interests of actors from several sectors as well as particular interests of states from the global North and South on the sovereignty over forest resources and forests as resources [6,13]. In this vein, regional regimes which consider forest issues directly or indirectly have drawn valuable attention to political and academic points of view in recent years [3,14-20]. Additionally, regional regimes with members from the same ecological contexts are more likely to develop a joint conception of what is perceived as a problem to be tackled. Hence, forests are put on the policy agenda in more coherent ways, than in settings with members from quite different contexts, such as the global North and South. Regional regimes have a beneficial influence on member states and their national interests, and they also support specific government bureaucracies and policy sectors to accomplish their goals [16]. For example, member states benefit through reducing contracting costs, providing sectoral focal points, enhancing information, and providing professionals to the secretariat [12].

Thus far, there has been a lot of research effort to analyze the structures established by international, state-driven formal agreements, conventions or treaty-based regimes such as the CBD (Convention on Biological Diversity) as well as non-governmental/private sector-initiated transnational regimes such as FSC (Forest Stewardship Council) forest certification [21]. It also enables regime research beyond formalistic and often rather juridical accounts, which qualify institutions' sets of rules as a regime only if based on formal explicit arrangements that are incorporated into documents (e.g., treaties or conventions) which Young [22] (p. 350) called 'constitutional' arrangements. However, the structure of highly formalized regimes includes the form of representation, the allocation of voting power, the relationship between representative bodies and management, the number of employees, sources of funding, annual budgets, and so on [23]. On the contrary, Young [22] (p. 342) found that "formalization is clearly not a necessary condition for the effective operation of international regimes." In fact, rather formalized forest-related and forest-focused regimes, e.g., on biodiversity [24] and on forest management [1,25], have been reported to have only limited effects. Hence, the study of highly versus weakly formalized regimes is necessary to enable comparison between the political options on a formal-informal continuum and for analyzing the implications for policy development by the respective type of regime. Biermann and Siebenhüner [26] observed that the influence of international bureaucracies (secretariats located within one of the member states) within highly formalized regimes on, e.g., biodiversity and climate change provides for quite different degrees of autonomy and authority over the regimes' policies.

However, no systematic and conceptual distinction has been made between regime structures, which once agreed, are rather persistent institutional settings, and regime policies, which are constantly developing over time [27-29], exceptions to this general observation include [30-34]. In addition, the analysis of regime complexes allows for comparisons across whole issue areas, especially fields which are not governed by a single, strongly formalized, unifying regime, or which from a global or Western perspective do not seem to be governed at all in the otherwise anarchic international system. In this way, the notion of a regime complex again opens the analytically valuable notions of implicit and informal aspects of regimes, which thus far have often suffered from rather formalistic applications of the regime concept. The key importance is that the comparison in this study is of regional regime responses to deforestation and forest degradation. 
To exemplify this conceptual distinction between regime structures and regime policies empirically, this study employs the cases of the highly formalized forest-related regional regime of the Association of Southeast Asian Nations (ASEAN) and the less formalized forest-focused Montréal Process (MP) regime. This study attempts not to be exhaustive but rather to demonstrate the ways in which they may have synergy or disparity in their institutional design and forest policy development. However, the aim of this study is to analyze the institutional design of this forest-related regime (i.e., ASEAN) and demonstrate how it addresses forest issues through active policy development compared to the forest-focused regime (i.e., MP). To do that, this study highlights in particular the historical constitutional adoption of both regimes, which explains the functional mechanisms of the whole institutions. At the same time, the empirical questions are how does ASEAN as a forest-related regime within a broader economic integration umbrella become relevant for forest issues in terms of regional forest policies, and how have both regimes developed forest policies within their structures with a high versus low degree of formality? We do so by pursuing the following guiding research questions:

1. How does the institutional design of ASEAN and MP make them forest-related/focused regimes structurally?

2. How do both regimes illustrate the adoption of coherent and consistent regional forest policies?

\section{Context: The ASEAN and MP Forest Regimes}

ASEAN is a regional intergovernmental organization comprising 10 countries in Southeast Asia which adhere to the principles of the United Nations Charter. Besides economic integration, this forest-related regime promotes sustainable development through protection of the region's environment, sustainable use of natural resources, preservation of cultural heritage, and ensuring a high quality of life (ASEAN Charter: Article 1, Clause 9). Meanwhile, MP is a non-treaty- and voluntary agreement-based regional forest-focused organization comprising 12 member countries in the northern and southern hemispheres aiming to conserve and sustainably manage their respective forests (see Figure 1 for both regimes).

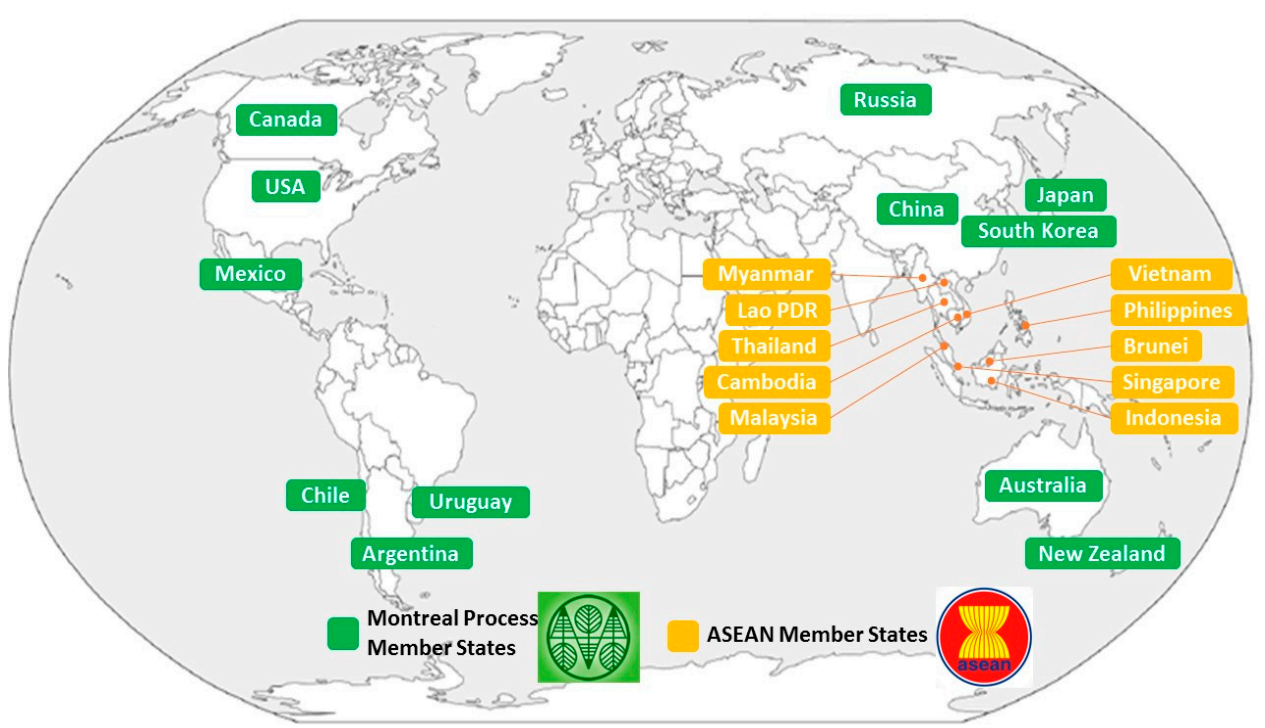

Figure 1. Member states of forest-related Association of Southeast Asian Nations (ASEAN) and forest-focused Montréal Process (MP) regional regimes (adapted from Google Maps).

However, ASEAN covers about $20 \%$ of global biodiversity, approximately $35 \%$ of global mangrove forests and $30 \%$ of coral reefs [35]. By contrast, MP covers $90 \%$ of the world's temperate and boreal forests, $49 \%$ of all forests, $58 \%$ of planted forests, $49 \%$ of global roundwood production, and $31 \%$ of the world's population [36]. The ASEAN officially expanded its scope to forestry in 1981 by the 
Jakarta Consensus and tries to resolve forest and environmental problems (e.g., haze air pollution, deforestation and forest degradation, climate change, biodiversity loss, water pollution) by cooperation and collaboration among the 10 ASEAN member states [37]. On the other hand, the creation of the forest-focused MP was a direct response to the Forest Principles developed at the 1992 Earth Summit [36]. The promotion of sustainable forest management (SFM) is of the utmost interest and priority to ASEAN member states through developing their respective country-specific national SFM criteria and indicators (C\&Is) [37]. Meanwhile, MP promotes SFM C\&I by simplifying the essential components of SFM by providing a common understanding, as well as a universal framework for describing each individual country's progress towards sustainability at a national level [36]. Indonesia holds the hegemonic position based on the highest gross domestic product (GDP) (US\$1,015,539.02 million in 2017) and forest area (91,010 thousand ha) among the ASEAN member states [38,39]. Meanwhile, Indonesia was blacklisted by ASEAN member states for haze pollution (particularly in Kalimantan and Sumatra) which affects mainly Malaysia and Singapore [16,40]. Among MP member states, the United States holds the top position in terms of GDP (US\$19,390,604.00 million in 2017) but Russia is the leading member based on forest area $(814,889.48$ thousand ha) $[38,39]$.

However, ASEAN and MP show a striking difference in the range of issues covered in and continuous change over time. ASEAN's foundation ideology was not only to reinforce the economic and social stability of the Southeast Asian region but also to establish stability and security from external intervention [41]. Besides economic integration, in 1977, ASEAN adopted agricultural cooperation for agriculture and forestry, aiming to strengthen international competitiveness in the food, agriculture, and forestry sectors [37]. Notably, in 1981, ASEAN took strong initiatives on forests through endorsement of the Jakarta Consensus on ASEAN Tropical Forestry, which was the first blueprint of the ASEAN common forestry policy and technical cooperation, cooperation in intra-ASEAN trade, and an ASEAN common stand on international issues on forestry [42]. In contrast, MP mainly focuses on SFM issues related to temperate and boreal forests since its initiation as a response to the Rio Forest Principles [36].

In order to have a high degree of comparability between cases, ASEAN and MP were selected as intergovernmental institutions [43]. The EU, as a potentially alternative case, was not selected as it has competencies of supranational nature [44], leading to quite distinct rivalry among its bureaucracy and Member States especially in forest-related issues [45].

\section{Theoretical Framework}

\subsection{International and Regional Forest Regimes}

An international regime is a set of governance arrangements for an issue area usually based on some form of agreement by the sovereign states, but the standard definition is provided by Krasner [46] (p. 186): "sets of implicit or explicit principles, norms, rules, and decision-making procedures around which actors' expectations converge in a given (issue) area of international relations." However, a large number of international land use regimes have evolved over recent decades, especially in the subordinate issue area of forest management and conservation [7-9]. Scholarship accounts for such a plethora of distinct regimes aiming to regulate (parts of) an issue area. According to Little [26,47], regimes may be particularly classified along their scalar scope as being either global, regional, or bilateral in nature. Consequently, a global regime complex (fragmented global governance architecture) covers all regimes in a given issue area, with no limiting criteria for membership based on spatial or other crucial functional proximity, and with global aspirations. In this vein, a regional regime can be understood as international arrangements between two or more actors from different countries, with limiting criteria for membership on the basis of spatial or other crucial functional proximity, and with a lack of global aspirations $[28,29,48]$, whereas the international relations (IR) concept is that a "region, in addition to its geographical dimension, also encompasses a political dimension" [49]. Hemmer and Katzenstein [50] (p. 575) argued strongly that while regions are often described in 
geographical terms, they are political creations and not fixed by geography. However, Jetschke and Lenz [51] defined regional regimes as institutionalized cooperation among three or more countries in a geographically restricted area.

International regime structure has attracted the attention of scholars over time [28,29]. Many of the regimes are only 'forest-related' rather than exclusively 'forest-focused'. Either specific forest issues are deeply entrenched in the regime's overall goals and structures by institutional design, traditionally being addressed through IR scholarship, or a broader regime with an initial scope of, for instance, broader economic integration over time, develops particular 'plans of action' regarding forest issues, traditionally referred to as a 'policy' in comparative government and policy analysis (PA) studies. In this study, we conceptualized forest-focused regimes, which establish forests as their main issue, and forest-related regimes which establish forests as a non-primary yet formal issue. The following Figure 2 shows the scenario.

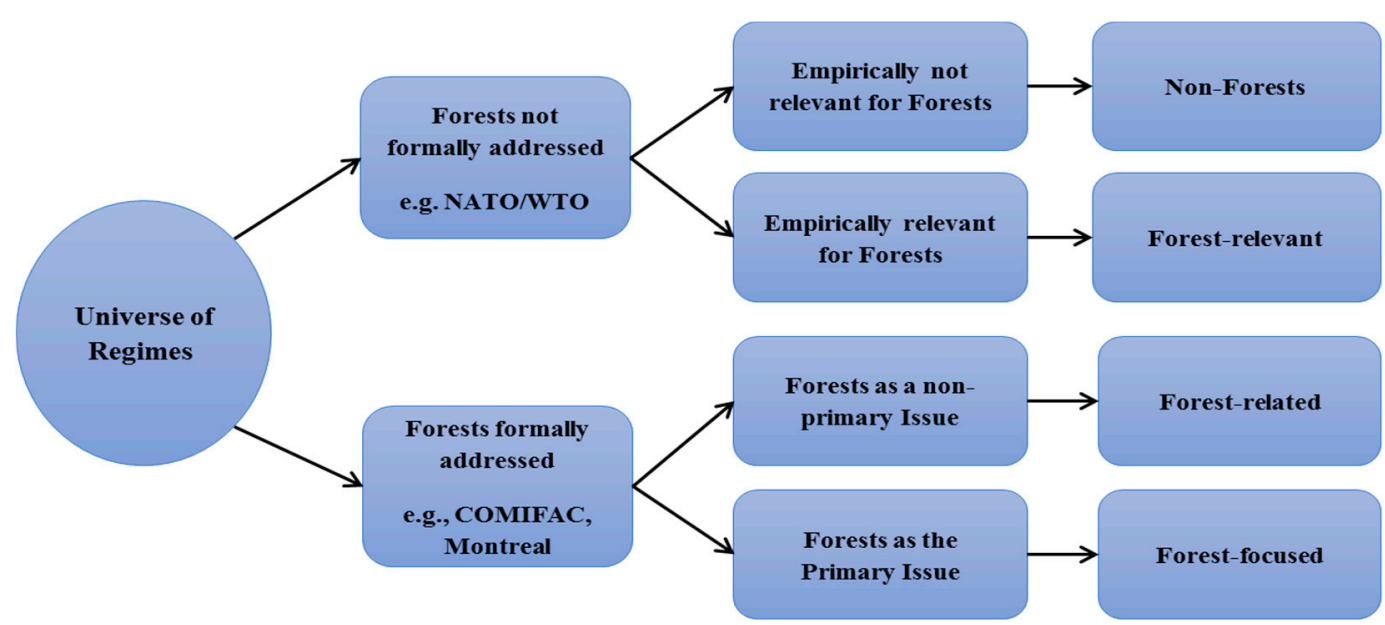

Figure 2. Types of forest regimes based on their empirical issue-focus adapted from [52].

\subsection{Comparing Institutional Design}

This study addressed institutional design theory in terms of how the institutions are essentially organized in different ways. Koremenos et al.'s [53] theory of 'rational institutional design', which has been used empirically with cases ranging from the World Trade Organization (WTO) to environmental issues $[28,29,48,54-60]$ will be applied to explain this study. This theory offers a systematic account of the wide range of design features that characterize (international) institutions [53] (p. 762). Importantly, institutional arrangements are best understood through 'rational design', which can explain much about institutions [53,61]. According to Koremenos et al. [53] (p. 763), institutions have five measurable variables: membership rules (Membership), scope of issues covered (Scope), centralization of tasks (Centralization), rules for controlling the institution (Control), and flexibility of arrangements (Flexibility). These five key assessable dimensions [53] are briefly explained in Table 1 below. 
Table 1. Five key measurable dimensions of an institution/regime adapted from [54].

\begin{tabular}{cl}
\hline Variable & \multicolumn{1}{c}{ Attributes } \\
$\begin{array}{c}\text { Membership rules } \\
\text { (Membership) }\end{array}$ & $\begin{array}{l}\text { Membership pattern might be either restrictive or exclusive. Regional states } \\
\text { may be the only members or non-governmental organizations (NGOs) may be } \\
\text { allowed. Additionally, a state dominant over other states for a long period of } \\
\text { time acts as a hegemon }\end{array}$ \\
\hline $\begin{array}{c}\text { Scope of issues covered } \\
\text { (Scope) }\end{array}$ & $\begin{array}{l}\text { Institution is established to address one or several specific issues. Issues might } \\
\text { have a wide range of coverage and change continuously over time }\end{array}$ \\
\hline $\begin{array}{c}\text { Centralization of tasks } \\
\text { (Centralization) }\end{array}$ & $\begin{array}{l}\text { Centralization revolves around the administrative performance of institutional } \\
\text { tasks; it focuses mainly on dissemination of information, bargaining and } \\
\text { transaction cost reduction, and the enhancement of enforcement }\end{array}$ \\
\hline $\begin{array}{c}\text { Rules for controlling the } \\
\text { institution (Control) }\end{array}$ & $\begin{array}{l}\text { Voting and financing of the institution are the key elements for determining } \\
\text { control. Other elements include whether all members have equal votes; } \\
\text { a minority holds veto power; and decisions are made through a simple majority, } \\
\text { a supermajority, or unanimity }\end{array}$ \\
\hline $\begin{array}{c}\text { Flexibility of arrangements } \\
\text { (Flexibility) }\end{array}$ & $\begin{array}{l}\text { Flexibility is the way institutions deal with new situations and can be of two } \\
\text { types: adaptive (e.g., an escape clause in a treaty) or transformative (i.e., built-in } \\
\text { arrangements or reactions to shocking events) }\end{array}$ \\
\hline
\end{tabular}

\subsection{Comparative Study on Policy Development}

Policy prospects and analyses on IR studies have not previously been extensively researched [1,62-65] because IR research has paid relatively little attention to the detailed, often technical, plans and courses of actions in cooperation through regimes, which are also regarded as regime policies [28,29]. A comparative approach allows the empirical and conceptual analysis of regional regimes' policy responses to a common event like a regional or global forest issue. In this vein, this study adopts Peter Hall's concept [66] to compare the development/design/arrangements of forest policies between the ASEAN and MP regional regimes. According to him, a policymaking process usually involves three central elements: the overarching clear goals that guide policy in a specific field, the more concrete policy instruments used to attain those goals, and the precise settings of these instruments [66] (p. 278). Following Hall's taxonomic view of policy components, this study adopted the following measurable constituents, which are called here the C\&I of policy development (Table 2). It will help to observe the overall depiction of forest policy development between ASEAN and MP regimes.

From Table 2, it can be seen that policy goals can be considered coherent if they are logically related to the same overall policy aims and can be achieved simultaneously without significant trade-offs [10]. Policy tools/instruments are consistent on one hand, when they work together to support at least one policy goal; on the other hand, they are inconsistent when they work against each other and are counterproductive (ibid). Glück et al. [71] argued that these policy elements match the policy design approach, which involves the deliberate and conscious attempt to define policy goals and connect them to instruments. This design style focuses on bundles or portfolios of tools and the interactive effects which occur when multiple tools are used over time in policy packages designed to address multiple goals [72]. In addition, this approach can determine the extent to which the policy goals of each component are internally coherent; the policy tools chosen to achieve the goals are consistent with each other; and the policy instruments themselves conform to the general preferences of the international target groups [71]. Policy instruments are specified as a bundle of techniques or means that are used to achieve policy goals $[69,73,74]$. With regional governance, the bureaus/secretariats seek to achieve their various goals by means of a wide range of regulatory, economic, and information policy tools [71].

Therefore, this analytical PA framework provides insights into the overall depiction of regional forest policy development between ASEAN and MP regimes in response to the challenges against deforestation and forest degradation. 
Table 2. Measurable criteria and indicators of policy components adapted from [32,66-70].

\begin{tabular}{|c|c|}
\hline Criterion & Indicators \\
\hline \multirow[b]{2}{*}{$\begin{array}{l}\text { Policy goals, aims or ends } \\
\text { (general types of ideas that } \\
\text { govern policy development) }\end{array}$} & The goals are mentioned explicitly in the regime's forest policy \\
\hline & $\begin{array}{l}\text { The goals are coherent, i.e., non-conflicting with each other (nor necessarily } \\
\text { reinforcing), e.g., simultaneously promoting in situ biodiversity conservation } \\
\text { and the conversion of natural forests to other uses }\end{array}$ \\
\hline $\begin{array}{l}\text { Policy instruments (policy } \\
\text { implementation } \\
\text { preferences) }\end{array}$ & $\begin{array}{l}\text { The policy means chosen/proposed to achieve the goals are consistent with each } \\
\text { other, e.g., projects, conventions, agreements, declarations, principles, } \\
\text { statements, decisions, resolutions, annual reports, publications }\end{array}$ \\
\hline \multirow{7}{*}{$\begin{array}{l}\text { Precise settings of } \\
\text { policy instruments }\end{array}$} & Specific types of instrument are utilized in the regime's climate policy \\
\hline & Regulatory instruments \\
\hline & Sanction/control mechanisms, secretariat mandates with reinforcement \\
\hline & Incentive instruments \\
\hline & $\begin{array}{l}\text { e.g., stable core funding, substantial projects funding, disincentives (e.g., fines } \\
\text { for illegal logging, taxes, fees) }\end{array}$ \\
\hline & Informational instruments \\
\hline & $\begin{array}{l}\text { Numerical indicators exist (e.g., } 15 \% \text { forest area increase), issue-specific periodic } \\
\text { reports issued within the regime, producing substantial public relation and } \\
\text { outreach materials }\end{array}$ \\
\hline
\end{tabular}

\section{Empirical Methods}

Essentially, qualitative content analysis was conducted for this study, since it is a widely and effectively used method of data analysis in political science with an aim to open up social reality through manifest text and non-manifest contexts [75-77]. In addition, the qualitative method raises both the reliability and validity of the data and supports a sound empirical basis for cause and effect analysis in the policy field [52,78-81].

However, the authors analyzed ASEAN and MP documents to investigate the hypothesis. Sahide et al., [82] argued that document analysis could be an essential approach for analyzing forest and environmental policy. For empirical data, the study relied heavily on the online-based repositories of both regional regimes, with some documents from reputable development partners (e.g., USAID, EU, BMZ, GIZ). A repository refers to a (physical or online) storage system of artefacts/materials (documents, data, information), used usually for reporting, analysis, and sharing [83,84]. An online-based repository allows researchers to collect important empirical materials more easily, and to conduct their studies in more efficient ways [84]. Furthermore, web-based open source systems act as a repository for intellectual outputs (research and educational materials) produced by an organization or institution [85] and give greater visibility and accessibility of the materials [86]. Other more specific empirical material sources were considered as supplementary data to enrich this analysis, i.e., public media discourses. This type of discourse is a network provided by the media where topics and problems between politics and society are processed into focused opinions [87]. Therefore, the authors found newspaper articles on institutional design structure (e.g., membership expansion) and forestry issues relevant to ASEAN and MP, but found relevant and consistent for this study on regime designs or structures, specifically ASEAN membership history and expansion.

All selected documents underwent a qualitative content analysis of the full text [88]. The analysis was conducted along the main analytical categories of the study, namely the institutional design and the regimes' forest policies. The analyses of the regimes' statutory and key institutional documents provided qualitative data on the institutional design of the regimes, including, (a) membership rules, (b) scope of issues covered, (c) centralization of tasks, (d) rules for controlling the institution, and (e) flexibility [53]. In this case, we developed questionnaires from that institutional design theory [53] and addressed based on content analysis (see the questionnaires in supplementary document, part: A). 
Additionally, forest-related policy documents were analyzed for eliciting data on the (a) issues being addressed by the regimes' forest policy, (b) goals of the policy, instruments for achieving those goals, and (c) on the implementing actors [69]. Relevant sections of the documents were coded with regard to providing insights into either of those categories. Most importantly, ASEAN and MP forest policy initiatives were chosen for the periods 2016-2025 (Strategic Plan of Action for ASEAN Cooperation on Forestry) and 2009-2015 (Conceptual Framework for the Montréal Process Strategic Action Plan), respectively; these are the latest adopted and ongoing strategic plans. This study analysed selected consistent policy instruments, whose main focus or objectives support to achieve any policy goal (s) of both regional regimes (see in supplementary document, part: B). This analysis leads to adequate understanding of the regimes' current interests and policy development circumstances.

\section{Results}

\subsection{Institutional Design}

\subsubsection{ASEAN and MP Membership and Centralization Structures}

ASEAN encompasses Brunei, Cambodia, Indonesia, Lao PDR or Lao People's Democratic Republic, Malaysia, Myanmar, the Philippines, Singapore, Thailand and Vietnam [37]. It was founded in 1967 by the nations of Indonesia, Malaysia, Philippines, Singapore, and Thailand and, over time, the group expanded to include its current 10 members (ibid). Notably, Papua New Guinea and East Timor are currently seeking accession to ASEAN as full members [89-91]. However, the latest expansion was the creation in 1997 of ASEAN Plus Three consisting of ASEAN, China, Japan, and Korea [92]. On the other hand, the countries of MP are Argentina, Australia, Canada, Chile, China, Japan, Mexico, New Zealand, Russia, Korea, the United States, and Uruguay [36]. The 10 founding members of MP were Australia, Canada, Chile, China, Japan, Korea, Mexico, New Zealand, Russia, and the United States (ibid). The memberships of ASEAN and MP are restrictive by design. For example, admission to ASEAN is geologically restricted to Southeast Asian states, and the candidate country must fulfil the admission criterion according to the Charter rules of Article 6 [93] (Chapter III); in contrast, MP membership is voluntary and inclusive of those countries with temperate and boreal forests [94] (p.2). Theoretically, the hegemonic position of any member state in both forest governance groups is not significant through the lens of financial contribution to the regime. Notably, it is undeniable that Indonesia is the leading hegemonic country among the ASEAN member states based on, for example, the ASEAN Secretariat being in Jakarta, GDP, forest area, and its hosting of high-profile events including the United Nations Climate Change Conference 2008 in Bali, the 2009 World Ocean Conference in Menado/Sulawesi, and the 2013 APEC (Asia-Pacific Economic Cooperation) Summit. In MP, the GDP-based hegemonic member states are America and China, and the forest area-based powerful member states are Russia and America. However, ASEAN started with the main issue of economic integration and prioritized several specific issues over time, forestry issues specifically functioning under the umbrella of the ASEAN Economic Community. MP is a specialized forest-focused regime and has dealt with SFM C\&I issues relating to temperate and boreal forests since its initiation as a response to the Rio Forest Principles.

The institutional tasks of the ASEAN and MP regimes are clearly described in the ASEAN Charter and MP Booklet 2015, respectively, which determine the duties and powers of the institutional works as well as laying down their principles of cooperation. The governance structure of ASEAN is classified into, briefly, the Summit, Secretariat, Coordinating Council, Community Councils, National Secretariat, Foundation, Sectoral Ministerial Bodies, Committee of Permanent Representatives, and ASEAN Intergovernmental Commission on Human Rights [93] (Chapters IV and X). MP is comprised of three distinctive organs: The Working Group (MPWG), Liaison Office (MPLO), and Technical Advisory Committee (MPTAC) [36]. The ASEAN Summit is the highest decision-making body and is composed of the heads of the ASEAN member states. The ASEAN Secretariat is located in Jakarta, Indonesia. The Secretariat works as a facilitator for member states, and also monitors progress on the 
implementation of ASEAN agreements and decisions as well as submitting an annual activity report to the Summit [93] (Article 11). In contrast, MPWG is the supreme body of MP which develops and improves the SFM C\&I. The voluntarily selected officials from MP member states became members of MPWG. MPLO MPTAC give support to MPWG [95]. Importantly, ASEAN deals with forest policy and strategy through the ASEAN Ministerial Meeting on Forestry (AMAF). AMAF gets assistance from the ASEAN Senior Officials on Forestry (ASOF) which consists of each member state's forest ministries, departments, or agencies who are responsible for forest issues. ASOF assists six working groups on Forest Management, the Convention on International Trade in Endangered Species of Wild Fauna and Flora (CITES) and Wildlife Enforcement, Forest Product Development, Forest and Climate Change, and Social Forestry Network [96]. Notably, the ASEAN Social Forestry Network (ASFN) was transformed in August 2016 into the ASEAN Working Group on Social Forestry (AWG-SF) with the main mandate of strengthening ASEAN Cooperation in Social Forestry through the sharing of information and knowledge [97]. This is a government-driven social forestry network in Southeast Asia that reports to ASOF then AMAF (ibid). It has objectives and a scope of work extended from those of the former ASFN, that link government forestry policy makers directly with other network members (ibid). Now, it contributes mainly to ASEAN Cooperation in Forestry Strategic Plans of Action, the ASEAN Multisectoral Framework on Climate Change: Agriculture and Forestry towards Food Security, and ASEAN Economic Community and ASEAN Socio-Cultural Community Roadmaps (ibid). However, the ASEAN Secretariat is differentiated from MPLO by its own activities and initiatives. For example, the ASEAN Secretariat adopted the Charter in 1997 and forced it to take effect in 1998 to stand against the financial crisis by the end of 1997.

ASEAN's external relations partners are designated as having Dialogue Partner, Sectoral Dialogue Partner, Development Partner, Special Observer, Guest or other status during the ASEAN Foreign Ministers Meeting. These external relations include, for example, economic and technical benefits from foreign direct investment (FDI) and development activities. According to recent data from the ASEAN Investment Report 2018, FDI flows to ASEAN increased significantly from \$123 billion in 2016 to $\$ 137$ billion in 2017 see details in Ref. [98]. At this point in time, ASEAN has 10 Dialogue Partners: Australia, Canada, China, EU, India, Japan, Korea, New Zealand, Russia, and the United States, as well as four Sectoral Dialogue Partners: Pakistan, Norway, Switzerland, and Turkey. ASEAN also has a Development Partnership with Germany. Papua New Guinea and Timor-Leste received Observer status in 1976 and 2002, respectively [99]. In this regard, the MPWG meeting is also open to other C\&I processes as well as international organizations or even non-governmental organizations (NGOs). MP has cooperated with ITTO (International Tropical Timber Organization), Forest Europe and the Food and Agriculture Organization (FAO) of the United Nations (UN) in order to improve the global forest reporting process towards SFM [36].

\subsubsection{Control Rules in ASEAN and MP Regimes}

The ASEAN Summit and MPWG are, respectively, the top policymaking bodies of ASEAN and MP $[36,93]$. ASEAN Summit meetings take place twice annually and in special or ad hoc situations when necessary. The chairmanship of ASEAN is rotated every year on the basis of the alphabetical order of the member states' English names [93]. The ASEAN member state which has the chairmanship takes the role of chair for all the institutional organs or structures of ASEAN including the ASEAN Summit. Differently, MPWG meetings take place once a year on a rotational basis, and ad hoc meetings are held when necessary by agreement of MP member states [100]. The host country which is predetermined at the previous meeting is required to decide the date and venue with the support of MPLO. The chairmanship of the MPWG meeting is also selected by the host MP member states. In both ASEAN Summit and MPWG meetings, decisions are taken by the basic principle of consultation and consensus among the member states on common understanding [36,93]. However, all ASEAN decisions must be unanimous. In addition, the ASEAN Secretariat-General which is the head of the Secretariat is appointed by the ASEAN Summit and serves a 5-year non-renewable term [93] (Chapter IV). Each 
of the Deputy Ministers in the Secretariat serves a 3-year term of office. The ASEAN Coordinating Council meeting is held at least twice a year [93] (Chapter IV). Each of the ASEAN Community Council meetings takes place twice a year and has its own rules of procedure [93]. Meanwhile, the MPLO location can be sporadically moved when needed, and one of the forest-specific officials of the host MP member state supports MPLO [95]. MPTAC intends to reduce the number of meetings in person and prefers to communicate in online-based meetings. Hence, MPTAC meetings take place when MPWG asks for aid [101]. Moreover, ASEAN and MP are operated by separate financing systems (detail in Table 3). Whereas ASEAN has an obligatory contribution from ASEAN member states to operate the Secretariat and to conduct its policy instruments, MP mainly relies on voluntary contributions and MP member states to cover the traveling costs to participate in meetings themselves.

Table 3. ASEAN and MP financing systems adapted from [93,95,100-103].

\begin{tabular}{|c|c|}
\hline ASEAN & MP \\
\hline Secretariat operational cost: & Liaison Office operational cost: \\
\hline Equal contribution of US\$1 million & $\begin{array}{l}\text { Baseline funding from a host country } \\
\text { Supplementary support from the other MP member } \\
\text { states (in case of need) }\end{array}$ \\
\hline ASEAN development fund: & Budgeted funds: \\
\hline Equal contribution of US\$1.1 million & $\begin{array}{c}\text { MP Working Group fund to assist MP Liaison Office } \\
\text { and MP Technical Advisory Committee }\end{array}$ \\
\hline $\begin{array}{l}\text { Common pool of financial resources to support the } \\
\text { implementation of its action plan }\end{array}$ & Voluntary contribution \\
\hline Intra-ASEAN investment: & Individual country funding: \\
\hline Financial investment by internal audits & $\begin{array}{l}\text { Participation costs for MP Working Group and MP } \\
\text { Technical Advisory Committee meetings }\end{array}$ \\
\hline Foreign direct investment: & Financial support among member states: \\
\hline $\begin{array}{l}\text { Financial investment by external audits } \\
\text { Majority of dialogue and development partners }\end{array}$ & $\begin{array}{c}\text { Aid for an MP member state which cannot afford to } \\
\text { participate in meetings }\end{array}$ \\
\hline
\end{tabular}

\subsubsection{Flexibility of the ASEAN and MP Regimes}

ASEAN and MP both pursue flexibility to face new circumstances. The ASEAN Charter as the constitution of ASEAN apparently mentions the procedure of amendments in Chapter XIII. First, ASEAN member states can propose amendments to the Charter, and the ASEAN Coordinating Council submits the proposal of amendments to the Charter to the ASEAN Summit. Then, amendments to the Charter are discussed in the Summit meeting and decided by the ASEAN Summit by consensus [93] (Chapter XIII). Additionally, the MP C\&I are monitored continuously and are open to be flexibly refined, for example, when the technology and research skill is advanced or the understanding of SFM is broadened. The set of indicators for criteria 1-6 were revised in 2007 during the 18th MPWG Meeting. The indicators for criteria 7 were revised in 2009 at the 20th MPWG Meeting [36]. Additionally, the MP member states can adjust the MP C\&I based on each country's national environment when these are applied in practice.

\subsection{Policy Development of ASEAN and MP Regimes}

This study appropriately limits forest policies by the last ASEAN and MP strategic plans adopted as their fundamental policy initiatives. The Strategic Plan of Action for ASEAN Cooperation on Forestry (2016-2025) and the 2009-2015 Conceptual Framework for the Montréal Process Strategic Action Plan were considered in order to represent the current circumstance of forest policy development (see Table 4). 
Table 4. Comparison of ASEAN and MP regional forest policies.

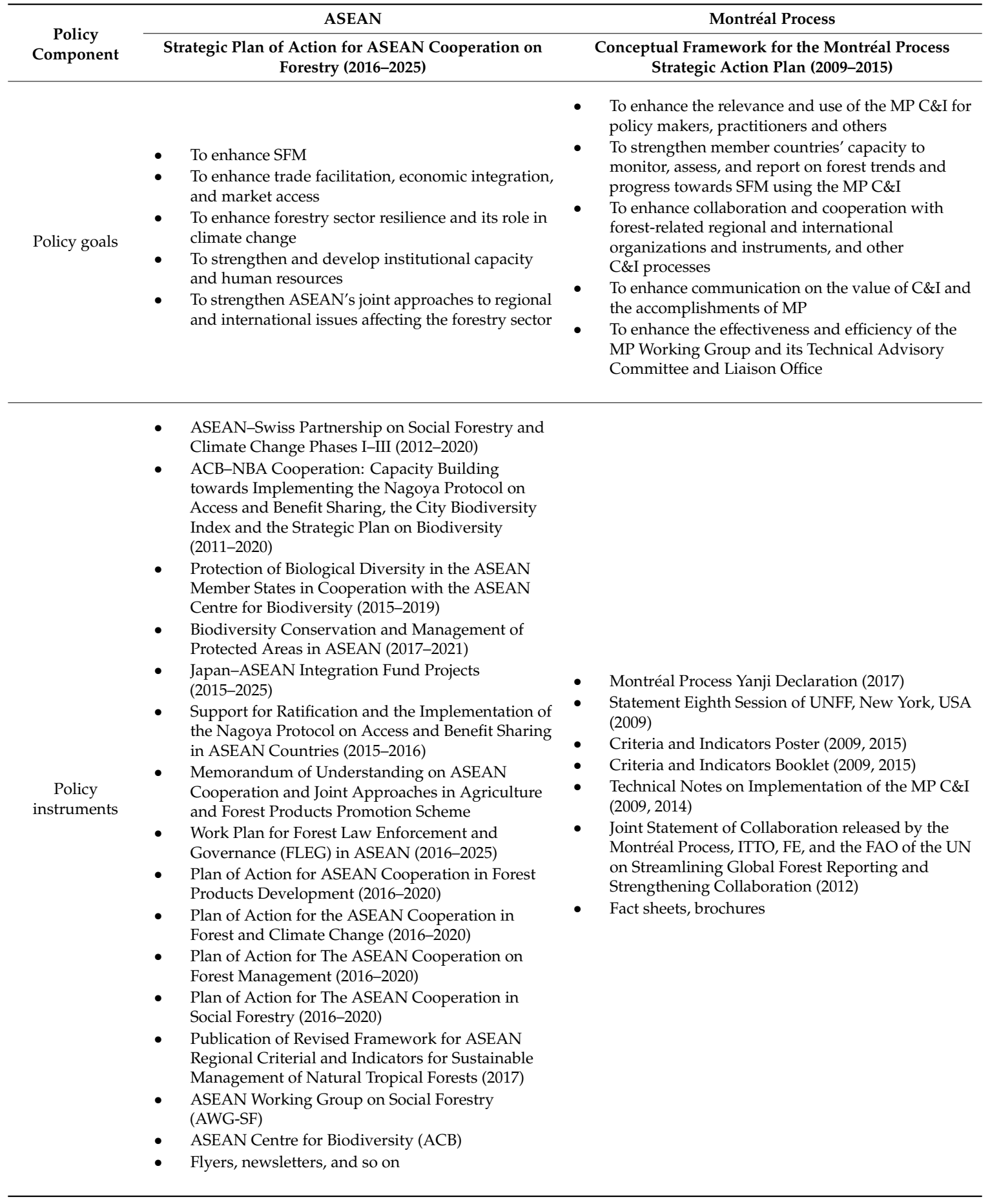


Table 4. Cont.

\begin{tabular}{|c|c|c|}
\hline \multirow{2}{*}{$\begin{array}{c}\text { Policy } \\
\text { Component }\end{array}$} & ASEAN & Montréal Process \\
\hline & $\begin{array}{c}\text { Strategic Plan of Action for ASEAN Cooperation on } \\
\text { Forestry (2016-2025) }\end{array}$ & $\begin{array}{l}\text { Conceptual Framework for the Montréal Process } \\
\text { Strategic Action Plan (2009-2015) }\end{array}$ \\
\hline \multirow[t]{2}{*}{$\begin{array}{c}\text { Precise setting } \\
\text { of policy } \\
\text { instruments }\end{array}$} & $\begin{array}{l}\text { Incentives: } \\
\text { - } \quad \text { Stable core funding based on member } \\
\text { state contributions } \\
\text { - } \quad \text { ASEAN Development Fund for covering all } \\
\text { scope-based policy programmes } \\
\text { - } \quad \text { Substantial amount of donor money observed } \\
\text { for forests } \\
\text { - No disincentives }\end{array}$ & $\begin{array}{l}\text { Incentives: } \\
\text { - } \quad \text { No core funding } \\
\text { - } \quad \text { Need-based and voluntary funding from } \\
\text { member states } \\
\text { - } \quad \text { No disincentives }\end{array}$ \\
\hline & $\begin{array}{l}\text { Information: } \\
\text { - } \quad \text { No numerical indicators } \\
\text { - } \quad \text { Issue-specific sporadic publications (e.g., C\&I for } \\
\quad \text { Sustainable Management of Natural } \\
\quad \text { Tropical Forests) } \\
\text { - } \quad \begin{array}{l}\text { Public relations and outreach materials (e.g., flyers, } \\
\text { newsletters, and so on) }\end{array}\end{array}$ & $\begin{array}{l}\text { Information: } \\
\text { - Numerical indicators (e.g., see the MP Fact } \\
\text { - Sheet 2015) } \\
\text { Issue-specific periodic reports (e.g., } \\
\text { country-level reports) } \\
\text { Public relations and outreach materials (e.g., } \\
\text { Christina Hendricks Promotes Sustainable Forestry } \\
\text { and the Montréal Process Public Service } \\
\text { Announcement Video) }\end{array}$ \\
\hline
\end{tabular}

Table 4 shows that both regimes clearly address the same number of goals (five) in their forest policies. Similarly, it is clear that both regimes address the same direction-based goals inherently under the broad umbrella of forests, except one of ASEAN's goals of "trade facilitation, economic integration and market access." To support each of the goals, ASEAN has adopted several goal-associated policy instruments such as donor-funded projects, action plans and MoUs (Memorandum of Understandings), and has established a working group and biodiversity center, newsletters, and flyers which are coherent and non-conflicting. Conversely, MP has adopted a number of policy instruments to achieve each of the policy goals, including statements, booklets, technical reports, fact sheets, and posters. Interestingly, the first priority goal of ASEAN's forest policy is elaborated as "protection and conservation of forests in an ecologically sound and integrated manner through regionally and internationally agreed C\&Is for SFM" [96] (p. 14), which matches the MP policy. To achieve this goal, ASEAN endorsed in 2017 a very strong policy tool: ASEAN Regional Criteria and Indicators for Sustainable Management of Natural Tropical Forests. However, there is significant disparity in regulatory instruments between the two forest governance bodies, which reflects their degree of formality based on institutional structure i.e., strong Secretariat vs. super-flexible Liaison Office. Indeed, ASEAN has two financial resources to support the implementation of forestry activities, while MP has no concern about incentive instruments but follows a need-based strategy. Without using the ASEAN Development Fund (ADF), ASEAN has implemented a number of forest-based projects through donor financial support. Thus, ASEAN attracts multiple donors with a wide variety of issues on forestry. These donors are usually ASEAN Dialogue or Development Partner countries and they offer not only financial support but also technical support for policy programmes and projects on forestry (see the project lists in Annex A). Regarding informational instruments, MP with its low degree of formality, is more advanced than ASEAN; one iconic example is Sustainable Forestry and Montréal Process Public Service Announcement video presented by Emmy Award nominee Christina Hendricks. Therefore, both regional regimes are committed to achieving sustainable development and environmental conservation through the conservation and sustainable management of tropical forests (for ASEAN) and temperate and boreal forests (for MP). To do so, AMAF and ASOF, including subsidiary bodies, work dedicatedly on forestry development activities to 
reach the vision that "forest resources are sustainably managed at the landscape level to meet societal needs, both socio-economically and culturally, of the present and future generations, and to contribute positively to sustainable development" [104] (p. 4). In the same way, MPWG, MPTAC, and MPLO work intensively on forestry development activities to advance the development and refinement of internationally agreed C\&Is for the conservation and sustainable management of temperate and boreal forests [94].

\section{Discussion}

\subsection{Comparing ASEAN and MP Forest Governance Design}

Both global and regional regimes reveal their diversity through the use of formal agreements, conventions, or treaties [22]. However, scholars have observed that the ASEAN forest-related regime has restricted membership admission and was established through strict adherence to the principles of the UN Charter and non-alignment. Since its inception, ASEAN as a multilateral organization has expanded its membership boundary over time. In this vein, Yoshimatsu [105]insisted that expansion of a regime's membership represents a changing trend of institutional value. MP's forest-focused regime started with 10 sovereign countries, now 12 after the expansion of membership admission, who have the same interest to work together for non-European boreal and temperate forests $[3,106]$. According to Taylor and Olson, having a large group increases the difficulty of cooperation, while Kenneth Oye stated that it increases the likelihood and robustness of cooperation [107]. For instance, the EU transformed through enlargement over time (grew from six countries to 28) [108]. ASEAN brought the forestry issue to the fore a long time after its formation, in 1981 through adoption of the Jakarta Consensus on ASEAN Tropical Forestry [42]. In this case, Sarker et al. [29] pointed out that environmental issues evolved as a policy, but not so much as a regime issue. They further stated that this may occur in order to adapt the regime to changing legal and political conditions and the demands of hegemons or other members (ibid). At the present time, ASEAN forestry cooperation is working towards implementation of the broader umbrella of the ASEAN Economic Community Blueprint 2025, with SFM the focusing issue (ibid), whereas MP has mainly focused on SFM issues related to temperate and boreal forests since its initiation as a response to the Rio Forest Principles [36]. From the beginning, MP has sought to implement C\&I to guide forest monitoring, assessment, and reporting and to institute forest policies and practices that foster progress towards SFM (ibid). MP has one of the most active C\&I processes in harmonized forest reporting [109,110].

However, it is evident from this analysis that ASEAN is a more highly formalized regime than MP. ASEAN is operational based on an intergovernmental treaty, whereas MP is considered as a transnational organization, mainly driven by sectoral bureaucracies [111]. From a structural point of view, regimes may be more or less formally articulated, and they may or may not be accompanied by explicit organizational arrangements [22]. With this low degree of organization, MP struggled to get global recognition/legitimacy at the beginning for fulfilling the interests a single member state, i.e., Canada, and finally achieved it through strong informal negotiation by Canada [3]. Consequently, since the United Nations Conference on Environment (UNCED), MP, ITTO, Forest Europe, and the FAO Global Forest Resources Assessment (GFRA) have utilized sophisticated C\&I frameworks for reporting on forest-related environmental, social and economic aspects [112]. Accordingly, the United Nations Forum on Forests (UNFF) acknowledged and mentioned that these four bodies continue to make significant progress by working together to promote SFM [112]. Scholars have criticized the implementation of C\&I and progress towards SFM besides the positive initiatives [109,113-115]. Equally important, with a high degree of formalization, are the strong initiatives of Indonesia and Malaysia using ASEAN solidarity to keep ramin (Gonystylus spp.), a high-quality wood species, in CITES Appendix A, in which it has been listed since 2004 [16].

This institutional formalization affects the class of organizations' administrative bureaucracies (i.e., Secretariat) which execute assigned central administrative or general secretary duties [23]. These 
bureaucracies affect the political processes in the regimes in various and distinct ways [116]. ASEAN and MP are run by the ASEAN Secretariat and MPLO, respectively. The ASEAN Secretariat has been located in Jakarta since its foundation and consists of around 300 staff including one Secretary-General, two Deputy Secretary-Generals, four Directors, 14 Assistant Director and Programme Coordinators, 23 Senior Officers, 27 Programme Officers, and 28 Assistant Programme Officers [117]. Expressly for forestry development, the ASEAN Secretariat provides support to the Senior Officials Meeting of the ASEAN Ministers on Agriculture and Forestry (SOM-AMAF), and AMAF with the support of SOM-AMAF provides policy guidance to subsidiary bodies, namely the ASEAN Working Group (AWG) on Forest Management, AWG Forest Product Development, AWG CITES and Wildlife Enforcement, AWG-SF, and AWG Forests and Climate Change $[96,104]$. On the other hand, MPLO and MPTAC mainly support the work of MPWG. As one of the MP member states hosts MPLO, the country assigns an MPLO task to one officer and voluntarily covers all the budget which is associated with the translation, printing, and dissemination of official MP documents and publications [36]. Moreover, Tarasofsky [118] argued that international forest regimes can be explained as the aggregation of norms, rules, standards, and procedures. The charter system as a constitutional law in regimes catalyzes the development of a legal order with regard to the hierarchically superior values [119]. The ASEAN Charter led to a number of institutional changes such as the coordination of organizational structure [120,121]. In addition, ASEAN became a rules-based organization as the Charter requires the strongest form of commitment among ASEAN member states [121], whereas MPWG argued that MP is a less formal regime but costs less and also offers countries more flexibility in how they participate compared with many other international forest-related initiatives [122].

\subsection{Comparison between ASEAN and MP Forest Policy Development}

This research has revealed that both regimes have same the political interests on forest issues (i.e., SFM) in their currently adopted forest polices. The broader goal of ASEAN forestry is to "enhance sustainable forest management for the continuous production of forest goods and services in a balanced way and ensuring forest protection and biological diversity conservation, as well as optimize their utilization, compatible with social and ecological sustainability" [104] (p.4). Meanwhile, MP addresses the broader goal of "criteria and indicators for the conservation and sustainable management of temperate and boreal forests" [123]. However, both regimes address clear and coherent policy goals internally; in particular, they are in the same direction or could have synergistic overlaps (Table 4). According to Young [124], institutional linkages are politically significant connections between multiple, nominally separated institutions, including regimes. On the whole, both regimes endorse and propose making choices on certain legal policy instruments. One synergetic example is that both regimes have been commonly active in coordinating and expanding commitments to promote SFM in terms of C\&I. For this, ASEAN endorsed a revised Framework for ASEAN Regional Criteria and Indicators for Sustainable Management of Natural Tropical Forests in 2017 in which the seven criteria have been aligned with those adopted in the ITTO's Criteria and Indicators for Sustainable Management of Tropical Forests, 2016 [93] (p. 5). In the same way, MP adopted the fifth edition of its Montréal Process Criteria and Indicators for the Conservation and Sustainable Management of Temperate and Boreal Forests booklet which presents the MP framework of seven criteria and 54 indicators, and a rationale for the inclusion of each indicator within the relevant criterion, together with contextual information. Notably, the ASEAN C\&I process collects data every second year; on the other hand, the MP C\&I monitoring and reporting process is mainly nationally based and is initiated every 5 years in most cases, or more frequently [109]. Additionally, ASEAN uses an online and offline monitoring, assessment and reporting (MAR) format at both national and forest management unit (FMU) levels for reviewing and assessing the implementation of ASEAN's SFM C\&Is [125]. According to a UNFF report [126], the main obstacles of ASEAN to SFM are forest governance issues at national and local levels due to increased power, roles and functions of local government units in implementing forest-related projects and activities; financing issues due to policy and market failures on the profit of unsustainable forest 
practices versus SFM; and land use change issues due to the competition for land among agriculture and forestry, food security and bio-energy, biomass/bio-energy and forestry, etc. [126].

Importantly, the choice of policy instruments will have a substantial impact on the success of a policy $[127,128]$. According to Howlett et al. [10], policy tools are consistent when they work together to support a policy goal. Congruence is achieved when a consistent instrument mix serves a coherent set of policy goals. In this vein, both regimes perform through utilizing a consistent policy mix. Supporting this result, it is noteworthy that these sets of regional multi-level agreements constitute a key building block in a strategy of diversifying and widening the policy instrument toolbox in order to embrace the complexity of forestry problems and overcome the deadlock that the international regime building pathway has encountered [10]. Additionally, effective regime interplay is achieved through the careful use of procedural policy instruments and other techniques common to multi-level governance in other sectors [129,130]. Regarding policy integration, Briassoulis [131] (p. 2) stated that "on the demand side, contemporary problems are complex and inter-related, defying treatment by means either of narrow, sectoral policies or of all encompassing, super-policies. On the supply side, numerous policies, related to particular aspects of one of more of these problems, exist." Integration involves the alteration of specific elements of an existing policy mix - the goals, objectives, and calibrations of existing policy tools-in order to produce a new mix, with the aim of avoiding counterproductive or sub-optimal policy outcomes associated with the old arrangement and enhancing its determinacy, effectiveness, and sustainability [10]. This has been illustrated empirically for both regimes by adopting/proposing policy tools to achieve policy goals (see Table 4). In fact, in the development of their current policies, both regimes have acted as forerunners for integrating sectoral policies into broader strategic frameworks in support of greater policy coherence and better cross-sectoral coordination, especially for integrating other important issues like biodiversity and climate change.

However, organizational factors could be regulating the precise setting of policy instruments. In this case, Majone stated that the performance of policy instruments depends more on the institutional framework within which they are used than on their technical characteristics [132,133]. Böcher and Töller [133] added that actors (e.g., member states) are interested in policy instruments which serve their interests in seemingly effective environmental policies where individual costs remain low. Importantly, this study observed that ASEAN applies a mix of regulatory and economic tools more significantly than information policy instruments for the promotion of sustainable development of forests. MP uses information policy tools more substantially than the other two tools, believing in low-cost and flexible organizational development for the promotion of SFM C\&Is globally. For example, ASEAN has implemented some big-budget projects which are supported financially by development partners (see Appendix A). MP has chiefly emphasized informational policy instruments and used online-based systems on a large scale, e.g., making a video with a famous actress and publishing booklets, numerically based country reports (New Zealand) and posters, while ASEAN has created transnational expert networks to support better-informed policymaking and scientific collaboration on forest-related issues [134].

Therefore, the treaty-based forest-related ASEAN and non-treaty-based forest-focused MP regional forest governance architectures have successfully applied new governance instruments to existing mixes in such a fashion, which is a potential decentralized approach to global forest policy design.

\section{Conclusions}

In concluding, it is worth reiterating the propositions presented earlier in this study of how ASEAN and MP have differences and similarities to each other through their institutional design structure, and forest policy development. However, the broad institutional design of ASEAN rather offers ample possibilities for issue linkages, e.g., to trade and poverty [135,136], food security [137], and a number of other issues possibly relevant for forests and the regime's forest policy. In contrast, the forest-focused institutional design and policy of the MP provides for clear, technically detailed guidance for forestry issues. It, however, does not provide for interlinkages to other, forest-related 
issues and relating frameworks as fruitfully as observed under ASEAN. Although the intention was for MP to be formalized at its fourth meeting, it still has the view of state-based coalitions willing to face SFM issues. While struggling with a high versus low degree of formality, both regimes have endorsed policy goals which assume a coherent and consistent approach towards achieving SFM against global deforestation and forest degradation. This research also opens the window for comparative study between or among other regional forest-related or focused regimes. This study concludes with the following self-explanatory Table 5, which clearly illustrates how both regimes contrast and correspond with each other based on significant observation. However, this study explored the regional forest policy with institutional design, but future research is needed for both regimes, specifically, the impact of reginal forest policy initiatives on the ground/national level of the Member States for sustainable forest management.

Table 5. Significant comparative observation between ASEAN and MP (Authors interpretation)

\begin{tabular}{|c|c|c|}
\hline Significant Observation & $\begin{array}{c}\text { Association of Southeast Asian } \\
\text { Nations (ASEAN) }\end{array}$ & The Montreal Process (MP) \\
\hline Regime type & $\begin{array}{l}\text { Treaty based forest-related regime } \\
\text { due to non-primary issue as } \\
\text { forests but significant for forests }\end{array}$ & $\begin{array}{l}\text { Non-treaty-based forest-focused } \\
\text { regime due to primary issue as } \\
\text { forests }\end{array}$ \\
\hline Membership rules & $\begin{array}{l}\text { Exclusive and restrictive by design } \\
\text { and followed by the constitution }\end{array}$ & $\begin{array}{l}\text { Inclusive and voluntarily by } \\
\text { design }\end{array}$ \\
\hline Decision-making process & Unanimity and highly political & $\begin{array}{l}\text { Not clearly mentioned but super } \\
\text { flexible }\end{array}$ \\
\hline Centralization of tasks & $\begin{array}{l}\text { Summit composed of the heads of } \\
\text { the member states }\end{array}$ & $\begin{array}{l}\text { Working Group consists of } \\
\text { voluntarily selected forest officials } \\
\text { from the member states }\end{array}$ \\
\hline Secretariat office & $\begin{array}{l}\text { Permanently located at one of the } \\
\text { member states, i.e., Indonesia }\end{array}$ & $\begin{array}{l}\text { Willingness of member states for } \\
\text { hosting, i.e., sporadically move } \\
\text { when needs }\end{array}$ \\
\hline Operational cost & $\begin{array}{l}\text { Equal amount of financial } \\
\text { contribution from member states }\end{array}$ & $\begin{array}{l}\text { Low cost beliefs with need-based } \\
\text { contribution }\end{array}$ \\
\hline Synergic on forest issues & \multicolumn{2}{|c|}{$\begin{array}{l}\text { All relevant forest issues (e.g., deforestation and forest degradation, } \\
\text { biodiversity, timber certification, greenhouse gas emission) condensed } \\
\text { under the broader label of sustainable forest management (SFM) }\end{array}$} \\
\hline Forest policy goals & \multicolumn{2}{|c|}{ Goals are mentioned explicitly and coherent each other } \\
\hline $\begin{array}{l}\text { Policy instruments (policy } \\
\text { implementation preferences) }\end{array}$ & \multicolumn{2}{|c|}{ The chosen/proposed tools are consistent with each other } \\
\hline $\begin{array}{l}\text { Precise settings of policy } \\
\text { instruments }\end{array}$ & $\begin{array}{l}\text { Highly importance for both } \\
\text { regulatory and incentive } \\
\text { instruments }\end{array}$ & $\begin{array}{l}\text { Informational instruments are } \\
\text { high priority }\end{array}$ \\
\hline $\begin{array}{l}\text { Synergistic overlaps on SFM } \\
\text { criterion and indicators (C\&Is) }\end{array}$ & \multicolumn{2}{|c|}{ Both regimes work on the same meaning of seven SFM criterion } \\
\hline Political will on forests & $\begin{array}{l}\text { Establishing/maintaining } \\
\text { development cooperation } \\
\text { nationally, regionally, and globally } \\
\text { for hunting external financial } \\
\text { resources }\end{array}$ & $\begin{array}{l}\text { Maintaining strong networking } \\
\text { systems for getting global } \\
\text { recognition through aligning the } \\
\text { SFM C\&Is with other regional and } \\
\text { global institutions }\end{array}$ \\
\hline
\end{tabular}

Supplementary Materials: The following are available online at http://www.mdpi.com/1999-4907/10/10/929/s1.

Author Contributions: Study design including hypotheses and methodology by L.G. and P.K.S. Data collection and analyses by P.K.S. and S.J. Data interpretation by S.J., P.K.S., L.G. All authors contributed substantially to writing the full paper. 
Acknowledgments: This research was funded by the German Research Foundation (DFG). We acknowledge the Open Access Publication Funds by the Georg-August University, Göttingen, Germany. We thank Professor Max Krott for his valuable comments and encouragement.

Conflicts of Interest: The authors declare no conflict of interest.

Appendix A

Table A1. The Number of Projects under Current ASEAN Forest Policies.

\begin{tabular}{|c|c|c|c|c|}
\hline Nr. & $\begin{array}{c}\text { Name of Forest Policy Projects and } \\
\text { Programs }\end{array}$ & Amount (US\$) & Funder & Period \\
\hline 1 & ASEAN-Wen Support Program & $1,000,000$ & USAID & $2006-2016$ \\
\hline 2 & $\begin{array}{c}\text { ASEAN-Swiss Partnership on Social } \\
\text { Forestry and Climate Change Phase I, } \\
\text { II }\end{array}$ & 224,383 & $\begin{array}{l}\text { Swiss Agency for } \\
\text { Development and } \\
\text { Cooperation (SDC) } \\
\text { and AWG-SF } \\
\text { Strategic Response } \\
\text { Fund (ASRF) }\end{array}$ & $2012-2020$ \\
\hline 3 & $\begin{array}{l}\text { Support for Ratification and the } \\
\text { Implementation of the Nagoya } \\
\text { Protocol on Access and Benefit } \\
\text { Sharing in ASEAN Countries }\end{array}$ & 300,000 & China & 2015-2016 \\
\hline 4 & $\begin{array}{l}\text { Protection of Biological Diversity in } \\
\text { the ASEAN Member States in } \\
\text { Cooperation with the ASEAN Centre } \\
\text { for Biodiversity }\end{array}$ & $21,534,528$ & BMZ, GIZ, KfW & 2015-2019 \\
\hline 5 & $\begin{array}{c}\text { Biodiversity Conservation and } \\
\text { Management of Protected Areas in } \\
\text { ASEAN }\end{array}$ & $11,333,962$ & EU & 2016-2021 \\
\hline
\end{tabular}

\section{References}

1. Dimitrov, R.S. Hostage to norms: States, Institutions and global forest politics. Glob. Environ. Politics 2005, 5, 1-22. [CrossRef]

2. Gale, F.; Cadman, T. Whose norms prevail? Policy networks, international organizations and "sustainable forest management". Soc. Nat. Resour. 2014, 27, 170-184. [CrossRef]

3. Singer, B. Putting the national back into forest-related policies: The international forests regime and national policies in Brazil and Indonesia. Int. For. Rev. 2008, 10, 523-537. [CrossRef]

4. McDermott, C.L.; Cashore, B.; Kanowski, P. Global Environmental Forest Policies: An International Comparison; Earthscan: London, UK, 2010; p. 392.

5. Arts, B.; Babili, I. Global Forest Governance: Multiple Practices of Policy Performance. In Forest and Nature Governance; Arts, B., Behagel, J., van Bommel, S., de Koning, J., Turnhout, E., Eds.; Springer: Dordrecht, The Netherlands, 2013; Volume 14, pp. 111-132.

6. Giessen, L. Reviewing the main characteristics of the international forest regime complex and partial explanations for its fragmentation. Int. For. Rev. 2013, 15, 60-70. [CrossRef]

7. Humphreys, D. Logjam: Deforestation and the Crisis of Global Governance; Routledge: Abingdon-on-Thames, UK, 2012.

8. McDermott, C.L.; Humphreys, D.; Wildburger, C.; Wood, P.; Marfo, E.; Pacheco, P.; Yasmi, Y. Mapping the core actors and issues defining international forest governance. In Embracing Complexity: Meeting the Challenges of International Forest Governance; Rayner, J., Buck, A., Katila, P., Eds.; IUFRO World Series 28; IUFRO: Vienna, Austria, 2010; pp. 19-36.

9. Rayner, J.; Buck, A.; Katila, P. Embracing Complexity: Meeting the Challenges of International Forest Governance. A Global Assessment Report; Prepared by the Global Forest Panel on the International Forest Regime; IUFRO World Series; IUFRO: Vienna, Austria, 2010; Volume 28, p. 172. 
10. Howlett, M.; Rayner, J.; Goehler, D.; Heidbreder, E.; Perron-Welch, F.; Rukundo, O.; Verkooijen, P.; Wildburger, C. Overcoming the challenges to integration. In Embracing Complexity: Meeting the Challenges of International Forest Governance; Rayner, J., Buck, A., Katila, P., Eds.; A Global Assessment Report; IUFRO World Series; IUFRO: Vienna, Austria, 2010.

11. Keohane, R.O.; Victor, D.G. The Regime Complex for Climate Change; The harvard project on international climate agreements; Belfer Center for Science and International Affairs, Harvard Kennedy School: Cambridge, MA, USA, 2010.

12. Keohane, R.O.; Victor, D.G. The regime complex for climate change. Perspect. Politics 2011, 9, 7-23. [CrossRef]

13. Fernández-Blanco, C.R.; Burns, S.L.; Giessen, L. Mapping the fragmentation of the international forest regime complex: Institutional elements, conflicts and synergies. Int. Environ. Agreem. Politics Law Econ. 2019, 19, 187-205. [CrossRef]

14. Arts, B.J.M.; Appelstrand, M.; Kleinschmit, D.; Pülzl, H.; Visseren-Hamakers, I.J.; Atyi, R.E.; Yasmi, Y. Discourses, actors and instruments in international forest governance. In Embracing Complexity: Meeting the Challenges of International Forest Governance. A Global Assessment Report, Prepared by the Global Forest Expert Panel on the International Forest Regime; International Union of Forest Research Organizations (IUFRO): Vienna, Austria, 2010; pp. 57-74.

15. Cashore, B.; Stone, M.W. Can legality verification rescue global forest governance? Analyzing the potential of public and private policy intersection to ameliorate forest challenges in Southeast Asia. For. Policy Econ. 2012, 18, 13-22. [CrossRef]

16. Giessen, L.; Sahide, M.A.K. Blocking, attracting, imposing, and aligning: The utility of ASEAN forest and environmental regime policies for strong member states. Land Use Policy 2017, 67, 13-26. [CrossRef]

17. Nurrochmat, D.R.; Dharmawan, A.H.; Obidzinski, K.; Dermawan, A.; Erbaugh, J.T. Contesting national and international forest regimes: Case of timber legality certification for community forests in Central Java, Indonesia. For. Policy Econ. 2016, 68, 54-64. [CrossRef]

18. Sahide, M.A.K.; Giessen, L. The fragmented land use administration in Indonesia-Analysing bureaucratic responsibilities influencing tropical rainforest transformation systems. Land Use Policy 2015, 43, 96-110. [CrossRef]

19. Sahide, M.A.K.; Maryudi, A.; Supratman, S.; Giessen, L. Is Indonesia utilising its international partners? The driving forces behind Forest Management Units. For. Policy Econ. 2016, 69, 11-20. [CrossRef]

20. Varkkey, H. Regional cooperation, patronage and the ASEAN Agreement on transboundary haze pollution. Int. Environ. Agreem. Politics Law Econ. 2014, 14, 65-81. [CrossRef]

21. Pattberg, P. Transnational environmental regimes. In Global Environmental Governance Reconsidered; Frank, B., Pattberg, P.H., Eds.; MIT Press: Cambridge, MA, USA, 2012; pp. 97-121.

22. Young, O.R. International regimes: Problems of concept formation. World Politics 1980, 32, 331-356. [CrossRef]

23. Koppell, J.G. World Rule: Accountability, Legitimacy, and the Design of Global Governance; University of Chicago Press: Chicago, IL, USA, 2010.

24. Harrop, S.R.; Pritchard, D.J. A hard instrument goes soft: The implications of the Convention on Biological Diversity's current trajectory. Global Environ. Chang. 2011, 21, 474-480. [CrossRef]

25. Jürging, J.; Giessen, L. Ein "Rechtsverbindliches Abkommen über die Wälder in Europa": Stand und Perspektiven aus rechts-und umweltpolitikwissenschaftlicher Sicht. Nat. Recht 2013, 35, 317-323. [CrossRef]

26. Biermann, F.; Siebenhüner, B. Managers of Global Change: The Influence of International Environmental Bureaucracies; MIT Press: Cambridge, MA, USA, 2009.

27. Giessen, L. Forests and the two faces of international governance: Customizing international regimes through domestic politics. Edw. Elgar Ser. New Horiz. Environ. Politics 2019. accepted.

28. Sarker, P.K.; Rahman, M.D.; Giessen, L. Regional governance by the South Asia Cooperative Environment Program (SACEP)? Institutional design and customizable regime policy offering flexible political options. Land Use Policy 2018, 77, 454-470. [CrossRef]

29. Sarker, P.K.; Rahman, M.D.; Giessen, L. Regional economic regimes and the environment: Stronger institutional design is weakening environmental policy capacity of the South Asian Association for Regional Cooperation. Int. Environ. Agreem. Politics Law Econ. 2019, 19, 1-34. [CrossRef]

30. Bernstein, S.; Cashore, B. Complex global governance and domestic policies: four pathways of influence. Int. Affairs. 2012, 88, 585-604. [CrossRef] 
31. Grundig, F. Dealing with the temporal domain of regime effectiveness: A further conceptual development of the Oslo-Potsdam solution. Int. Environ. Agreem. Politics Law Econ. 2012, 12, 111-127. [CrossRef]

32. Rayner, J.; Howlett, M. Conclusion: Governance arrangements and policy capacity for policy integration. Policy Soc. 2009, 28, 165-172. [CrossRef]

33. Stokke, O. (Ed.) Aid and Political Conditionality; Routledge: London, UK, 2013. [CrossRef]

34. Underdal, A. Meeting common environmental challenges: the co-evolution of policies and practices. Int. Environ. Agreem. Politics Law Econ. 2013, 13, 15-30. [CrossRef]

35. ACB. Protection of Biological Diversity in the ASEAN Member States in Cooperation with the ASEAN Centre for Biodiversity. 2019. Available online: https://aseanbiodiversity.org/key_programme/protection-ofbiological-diversity-in-the-asean-member-states-in-cooperation-with-the-asean-centre-for-biodiversitycare4biodiv/ (accessed on 13 February 2019).

36. Montreal Process. The Montréal Process Criteria and Indicators for the Conservation and Sustainable Management of Temperate and Boreal Forests. 2015. Available online: https://www.montrealprocess.org/ documents/publications/techreports/MontrealProcessSeptember2015.pdf (accessed on 15 November 2018).

37. ASEAN. ASEAN Cooperation in Food, Agriculture and Forestry Major Achievements. 2019. Available online: https://asean.org/?static_post=asean-cooperation-in-food-agriculture-and-forestry-majorachievements (accessed on 15 January 2019).

38. WB (World Bank). GDP (Current US\$). 2019. Available online: https://data.worldbank.org/indicator/NY. GDP.MKTP.CD (accessed on 15 January 2019).

39. FAO (Food and Agriculture Organization of the United Nations). The Global Forest Resources Assessment. 2015. Available online: http://www.fao.org/forest-resources-assessment/past-assessments/fra-2015/en/ (accessed on 15 May 2019).

40. Heiduk, F. Indonesia in ASEAN: Regional Leadership between Ambition and Ambiguity; (SWP Research Paper, 6/2016); Stiftung Wissenschaft und Politik -SWP- Deutsches Institut für Internationale Politik und Sicherheit: Berlin, Germany, 2016; Available online: https://nbn-resolving.org/urn:nbn:de:0168-ssoar-46859-8 (accessed on 21 October 2019).

41. ASEAN. The ASEAN Declaration (Bangkok Declaration) Bangkok. 1967. Available online: https://asean.org/ the-asean-declaration-bangkok-declaration-bangkok-8-august-1967/ (accessed on 14 October 2018).

42. AMAF. Jakarta Consensus on Forestry. 1981. Available online: https://cil.nus.edu.sg/wp-content/uploads/ formidable/18/1981-Jakarta-Consensus-on-ASEAN-Tropical-Forestry-pdf.pdf (accessed on 14 May 2019).

43. Krell, G. Weltbilder und Weltordnung: Einführung in die Theorie der Internationalen Beziehungen, 4th ed.; Nomos: Baden, Germany, 2009.

44. Sandholtz, W.; Sweet, A.S. European Integration and Supranational Governance; OUP Oxford: Oxford, UK, 1998.

45. Wolfslehner, B.; Aggestam, F.; Hurmekoski, E.; Kulikova, E.; Lindner, M.; Nabuurs, G.J.; Hendriks, C.M.A. Study on Progress in Implementing the EU Forest Strategy-Evaluation Study; European Forest Institute: Joensuu, Finland, 2018.

46. Krasner, S.D. Structural Causes and Regime Consequences: Regimes as Intervening Variables. Int. Organ. 1982, 36, 185-205. [CrossRef]

47. Little, R. International regimes. In The Globalization of World Politics; Baylis, J., Smith, S., Eds.; Oxford University Press: Oxford, UK, 2001; pp. 299-330.

48. Bezerra, J.C.; Sindt, J.; Giessen, L. The rational design of regional regimes: Contrasting Amazonian, Central African and Pan-European Forest Governance. Int. Environ. Agreem. Politics Law Econ. 2018, 18, 635-656. [CrossRef]

49. Flemes, D. Regional Leadership in the Global System: Ideas, Interests and Strategies of Regional Powers; Routledge: Abingdon-on-Thames, UK, 2016.

50. Hemmer, C.; Katzenstein, P.J. Why is there no NATO in Asia? Collective identity, regionalism, and the origins of multilateralism. Int. Organ. 2002, 56, 575-607. [CrossRef]

51. Jetschke, A.; Lenz, T. Does regionalism diffuse? A new research agenda for the study of regional organizations. J. Eur. Public Policy 2013, 20, 626-637. [CrossRef]

52. Giessen, L.; Sarker, P.; Rahman, M. International and domestic sustainable forest management policies: Distributive effects on power among state agencies in Bangladesh. Sustainability 2016, 8, 335. [CrossRef]

53. Koremenos, B.; Lipson, C.; Snidal, D. The rational design of international institutions. Int. Organ. 2001, 55, 761-799. [CrossRef] 
54. Kydd, A. Trust building, trust breaking: The dilemma of NATO enlargement. Int. Organ. 2001, 55, 801-828. [CrossRef]

55. Mattli, W. Private justice in a global economy: From litigation to arbitration. Int. Organ. 2001, 55, 919-947. [CrossRef]

56. Mitchell, R.; Keilbach, P. Situation structure and institutional design: reciprocity, coercion, and Exchange. Int. Organ. 2001, 55, 891-917. [CrossRef]

57. Oatley, T.H. Multilateralizing trade and payments in postwar Europe. Int. Organ. 2001, 55, 949-969. [CrossRef]

58. Pahre, R. Most-favored-nation clauses and clustered negotiations. Int. Organ. 2001, 55, 859-890. [CrossRef]

59. Rosendorff, B.P.; Milner, H.V. The optimal design of international trade institutions: uncertainty and escape. Int. Organ. 2001, 55, 829-857. [CrossRef]

60. Trudeau, H.; Duplessis, I. Insights from global environmental governance. Int. Stud. Rev. 2013, 15, 562-589.

61. Martin, L.L.; Simmons, B.A. Theories and empirical studies of international institutions. Int. Organ. 1998, 52, 729-757. [CrossRef]

62. Levy, M.A.; Young, O.R.; Zürn, M. The study of international regimes. Eur. J. Int. Relat. 1995, 1, $267-330$. [CrossRef]

63. Howlett, M.; Rayner, J. Policy divergence as a response to weak international regimes: The formulation and implementation of natural resource new governance arrangements in Europe and Canada. Policy Soc. 2005, 24, 16-45. [CrossRef]

64. Levi-Faur, D. The governance of international telecommunications competition: cross international study of international policy regimes. Compet. Chang. 1999, 4, 93-120. [CrossRef]

65. Oberthur, S.; Tanzler, D. The influence of international regimes in policy diffusion: The Kyoto protocol and climate policies in the European Union. Z. Umweltpolit. Umweltr. 2006, $29,283$.

66. Hall, P.A. Policy paradigms, social learning, and the state: The case of economic policymaking in Britain. Comp. Politics 1993, 25, 275-296. [CrossRef]

67. Cashore, B.; Howlett, M. Punctuating which equilibrium? Understanding thermostatic policy dynamics in Pacific Northwest forestry. Am. J. Political Sci. 2007, 51, 532-551. [CrossRef]

68. Howlett, M.; Cashore, B. Conceptualizing public policy. In Comparative Policy Studies; Springer: Berlin/Heidelberg, Germany, 2014; pp. 17-33.

69. Krott, M. Forest Policy Analysis; Springer Science \& Business Media: Berlin/Heidelberg, Germany, 2005.

70. Krott, M.; Bader, A.; Schusser, C.; Devkota, R.; Maryudi, A.; Giessen, L.; Aurenhammer, H. Actor-centred power: the driving force in decentralised community based forest governance. For. Policy Econ. 2014, 49, 34-42. [CrossRef]

71. Glück, P.; Angelsen, A.; Appelstrand, M.; Assembe-Mvondo, S.; Auld, G.; Hogl, K.; Wildburger, C. Core Components of the International Forest Regime Complex; IUFRO (International Union of Forestry Research Organizations Secretariat): Vienna, Austria, 2010; Volume 28.

72. Howlett, M.; Mukherjee, I.; Woo, J.J. From tools to toolkits in policy design studies: The new design orientation towards policy formulation research. Policy Politics 2015, 43, 291-311. [CrossRef]

73. Howlett, M.; Ramesh, M.; Perl, A. Studying Public Policy: Policy Cycles and Policy Subsystems; Oxford University Press: Oxford, UK, 2009; Volume 3.

74. Vedung, E. Policy instrument: Typologies and theories. In Carrots, Sticks \& Sermons Policy Instruments and Their Evaluation; Bemelmans-Videc, M.L., Rist, R.C., Vedung, E.O., Eds.; Transaction Publishers: Piscataway, NJ, USA, 1998; pp. 21-58.

75. Burns, S.L.; Giessen, L. Dismantling comprehensive forest bureaucracies: Direct access, the World Bank, agricultural interests, and neoliberal administrative reform of forest policy in Argentina. Soc. Nat. Resour. 2016, 29, 493-508. [CrossRef]

76. Kreuger, L.; Neuman, W.L. Social Work Research Methods: Qualitative and Quantitative Approaches: With Research Navigator; Pearson/Allyn and Bacon: Boston, MA, USA, 2006.

77. Rahman, M.S.; Giessen, L. Mapping international forest-related issues and main actors' positions in Bangladesh. Int. For. Rev. 2014, 16, 586-601. [CrossRef]

78. Rahman, M.S.; Sarker, P.K.; Giessen, L. Power players in biodiversity policy: Insights from international and domestic forest biodiversity initiatives in Bangladesh from 1992 to 2013. Land Use Policy 2016, 59, 386-401. [CrossRef] 
79. Sarker, P.K.; Rahman, M.D.; Giessen, L. Empowering state agencies through national and international community forestry policies in Bangladesh. Int. For. Rev. 2017, 19, 79-101. [CrossRef]

80. Schusser, C.; Krott, M.; Devkota, R.; Maryudi, A.; Salla, M.; Yufanyi Movuh, M.C. Sequence design of quantitative and qualitative surveys for increasing efficiency in forest policy research. Allg. For. Jagdztg. (AFJZ) 2012, 183, 75-83.

81. Schusser, C.; Krott, M.; Movuh, M.C.Y.; Logmani, J.; Devkota, R.R.; Maryudi, A.; Bach, N.D. Powerful stakeholders as drivers of community forestry—Results of an international study. Forest Policy Econ. 2015, 58, 92-101. [CrossRef]

82. Sahide, M.A.K.; Fisher, M.R.; Maryudi, A.; Dhiaulhaq, A.; Wulandari, C.; Kim, Y.-S.; Giessen, L. Deadlock opportunism in contesting conservation areas in Indonesia. Land Use Policy 2018, 77, 412-424. [CrossRef]

83. Bernstein, P.A.; Dayal, U. An overview of repository technology. VLDB 1994, 94, 705-713.

84. Rahayu, S.; Laraswati, D.; Pratama, A.A.; Permadi, D.B.; Sahide, M.A.; Maryudi, A. Research trend: Hidden diamonds-The values and risks of online repository documents for forest policy and governance analysis. For. Policy Econ. 2019, 100, 254-257. [CrossRef]

85. Tansley, R.; Bass, M.; Stuve, D.; Branschofsky, M.; Chudnov, D.; McClellan, G.; Smith, M. The DSpace institutional digital repository system: Current functionality. In Proceedings of the 2003 Joint Conference on Digital Libraries, Houston, TX, USA, 27-31 May 2003; IEEE: Piscataway, NJ, USA, 2003; pp. 87-97.

86. Smith, M.; Barton, M.; Bass, M.; Branschofsky, M.; McClellan, G.; Stuve, D.; Walker, J.H. DSpace: An Open Source Dynamic Digital Repository. D-Lib Magazine. 2003, Volume 9. Number 1. Available online: https://dspace.mit.edu/bitstream/handle/1721.1/29465/D-Lib\%20article\%20January\%202003.htm? sequence $=1$ (accessed on 15 January 2019).

87. Kleinschmit, D.; Krott, M. The media in forestry: Government, governance and social visibility. In Public and Private in Natural Resource Governance: A False Dichotomy; Routledge: London, UK, 2008; pp. 127-141.

88. Bryman, A. Social Research Methods; Oxford University Press: Oxford, UK, 2016.

89. GMA News Online. Papua New Guinea Asks RP Support for ASEAN Membership Bid. 2009. Available online: https://www.gmanetwork.com/news/news/nation/154860/papua-new-guinea-asks-rp-support-forasean-membership-bid/story/ (accessed on 21 June 2019).

90. Daily Express. Timor Leste Is Ready to Join ASEAN Grouping. 2015. Available online: http://www. dailyexpress.com.my/news.cfm?NewsID=98869 (accessed on 21 June 2019).

91. Waybackmachine. Somare Seeks PGMA's Support for PNG's ASEAN Membership Bid. 2009. Available online: https://web.archive.org/web/20100306192700/http://www.op.gov.ph/index.php?option= com_content\&task=view\&id=22879\&Itemid=2 (accessed on 21 June 2019).

92. World Economic Forum. What Is ASEAN? 2019. Available online: https://www.weforum.org/agenda/2017/ 05/what-is-asean-explainer/ (accessed on 12 May 2019).

93. ASEAN Secretariat. The ASEAN Charter: 21th Reprint. 2017. Available online: https://asean.org/ storage/2017/07/8.-July-2017-The-ASEAN-Charter-21th-Reprint-with-Updated-Annex-1.pdf (accessed on 14 November 2018).

94. Montreal Process. The Montréal Process Strategic Documents. In Proceedings of the 27th Montréal Process Working Group Meeting, Nelson, New Zealand, 13-17 November 2017.

95. Montreal Process. Annex G: Working Group Meeting Report. In Proceedings of the 21st Montreal Process Working Group Meeting, Hilo, HI, USA, 1-4 June 2010; Available online: https://www.montrealprocess.org/ Resources/Meeting_Reports/Working_Group/21_e.shtml (accessed on 12 November 2018).

96. ASEAN. 2016-2025 Vision and Strategic Plan for ASEAN Cooperation in Food, Agriculture, and Forestry. 2015. Available online: https://cil.nus.edu.sg/wp-content/uploads/formidable/18/2016-2025-Vision-and-StgcPlan-ASEAN-Coop-in-Food-Agri-Forestry.pdf (accessed on 18 December 2018).

97. AWG-SF. History. 2019. Available online: http://www.awg-sf.org/ (accessed on 21 June 2019).

98. ASEAN Investment Report. In Foreign Direct Investment and the Digital Economy in ASEAN Jakarta; ASEAN Secretariat: Jakarta, Indonesia, 2018.

99. Merced, L.D.C. Partners for Change Understanding the External Relations of ASEAN; Foreign Service Institute: Arlington, VA, USA, 2017. Available online: http://hdl.handle.net/11540/7440 (accessed on 15 January 2019).

100. Montreal Process. Annex F: Working Group Meeting Report. In Proceedings of the 21st Montreal Process Working Group Meeting, Hilo, HI, USA, 1-4 June 2010; Available online: https://www.montrealprocess.org/ Resources/Meeting_Reports/Working_Group/21_e.shtml (accessed on 12 November 2018). 
101. Montreal Process. Annex H: Working Group Meeting Report. In Proceedings of the 21st Montreal Process Working Group Meeting, Hilo, HI, USA, 1-4 June 2010; Available online: https://www.montrealprocess.org/ Resources/Meeting_Reports/Working_Group/21_e.shtml (accessed on 12 November 2018).

102. ASEAN. Agreement for the Establishment of a Fund for ASEAN Rules Governing the Control, Disbursement and Accounting of the Fund for the ASEAN Cameron Highlands. 1969. Available online: https://asean.org/?static_post=asean-secretariat-basic-documents-agreement-for-the-establishment-ofa-fund-for-asean-rules-governing-the-control-disbursement-and-accounting-of-the-fund-for-aseancameron-highlands-17-december-1969-2 (accessed on 12 May 2019).

103. ASEAN. Agreement on the Establishment of the ASEAN Development Fund Vientiane. 26 July 2005. Available online: https://asean.org/?static_post=agreement-on-the-establishment-of-the-asean-development-fundvientiane-26-july-2005-2 (accessed on 12 May 2019).

104. ASEAN. Strategic Plan of Action for ASEAN Cooperation on Forestry (2016-2025) 2016. Available online: https://asean.org/storage/2016/10/Strategic-Plan-of-Action-for-ASEAN-Cooperation-on-Forestry2016-2025.pdf (accessed on 18 December 2018).

105. Yoshimatsu, H. International Regimes, International Society, and Theoretical Relations. Int. Stud. 1991, 17, 42.

106. Montreal Process. Working Group Meeting Report. In Proceedings of the 2nd Meeting of the Working Group, Delhi, India, 28 July 1994; Available online: https://www.montrealprocess.org/Resources/Meeting_Reports/ Working_Group/2_e.shtml (accessed on 16 January 2019).

107. Kahler, M. Institution-building in the Pacific; Graduate School of International Relations and Pacific Studies, University of California: San Diego, CA, USA, 1993; Volume 93.

108. EU (European Union). Enlargement and Stabilisation and Association Process; Document no. 16991/14; General Secretariat of the Council: Brussels, Belgium, 16 December 2014; Available online: https://www.consilium. europa.eu/en/policies/enlargement/ (accessed on 12 January 2019).

109. Linser, S.; Wolfslehner, B.; Bridge, S.; Gritten, D.; Johnson, S.; Payn, T.; Robertson, G. 25 Years of Criteria and Indicators for Sustainable Forest Management: How Intergovernmental C\&I Processes Have Made a Difference. Forests 2018, 9, 578.

110. McDermott, C.L.; O'Carroll, A.; Wood, P. International Forest Policy-the Instruments, Agreements and Processes that Shape It; UN Department of Economic and Social Affairs, United Nations Forum on Forests (UNFF) Secretariat: New York, NY, USA, 2007.

111. Willetts, P. Transnational actors and international organizations in global politics. In The Globalisation of World Politics, 2nd ed.; Baylis, J.B., Smith, S., Eds.; Oxford University Press: Oxford, UK; New York, NY, USA, 2001; pp. 356-383.

112. Montreal Process Joint statement of The Montréal Process, International Tropical Timber Organization, FOREST EUROPE, and the Food and Agriculture Organization of the United Nations' Global Forest Resources Assessment. 5 January 2012. Available online: https://www.montrealprocess.org/Resources/ Official_Statements/index.shtml (accessed on 25 January 2019).

113. Chandran, A.; Innes, J.L. The state of the forest: Reporting and communicating the state of forests by Montreal Process countries. Int. For. Rev. 2014, 16, 103-111. [CrossRef]

114. Bayne, K.M.; Höck, B.K.; Spence, H.R.; Crawford, K.A.; Payn, T.W.; Barnard, T.D. New Zealand school children's perceptions of local forests and the Montréal Process Criteria and Indicators: Comparing local and international value systems. N. Z. J. For. Sci. 2015, 45, 20. [CrossRef]

115. Mcginley, K.A.; Cubbage, F.W. Examining Forest Governance in the United States Through the Montréal Process Criteria and Indicators Framework. Int. For. Rev. 2017, 19, 192-208.

116. Biermann, F.; Bauer, S. Managers of Global Governance. Assessing and Explaining the Influence of International Bureaucracies; Global Governance Working Paper; The MIT Press: Cambridge, MA, USA; London, UK, 2005.

117. ASEAN. The ASEAN Secretariat: Basic Mandate, Functions and Composition. 2012. Available online: https: //asean.org/?static_post=asean-secretariat-basic-documents-asean-secretariat-basic-mandate-2 (accessed on 12 November 2018).

118. Tarasofsky, R.G. Assessing the International Forest Regime; IUCN Environmental Policy and Law Paper No. 37; International Union for the Conservation of Nature and Natural Resources: Gland, Switzerland, 1999.

119. De Wet, E. The international constitutional order. Int. Comp. Law Q. 2006, 55, 51-76. [CrossRef] 
120. Koh, T.; Woon, W.; Tan, A.; Sze-Wei, C. Charter makes ASEAN stronger, more united and effective. Straits Times, 8 August 2007.

121. Sukma, R. ASEAN beyond 2015: The Imperatives for Further Institutional Changes; ERIA Discussion Paper Series; ERIA Annex Office: Jakarta Pusat, Indonesia, 2014.

122. Montreal Process. Regional and Sub-Regional Inputs to UNFF11. 2014. Liaison Officer of the Montréal Process Working Group, Japan. Available online: https:/www.google.com/url?sa=t\&rct=j\&q=\&esrc=s\&source= web\&cd $=7 \& \mathrm{cad}=$ rja\&uact $=8 \&$ ved $=2$ ahUKEwiagIuqwKXiAhXD-qQKHQ-wATEQFjAGegQIBxAC\& url=https \%3A\%2F\%2Fwww.un.org\%2Fesa\%2Fforests\%2Fwp-content\%2Fuploads\%2F2015\%2F06\% 2FMontreal-Process.pdf\&usg=AOvVaw0ssL7M_7iHar_msKJI9Ac4 (accessed on 18 May 2019).

123. Montreal Process Annex E. 2009. Available online: https://www.montrealprocess.org/documents/meetings/ working/an-5.pdf (accessed on 18 May 2019).

124. Young, O.R. International Governance: Protecting the Environment in a Stateless Society; Cornell University Press: Ithaca, NY, USA, 1994.

125. ASEAN. ASEAN Criteria and Indicators for Sustainable Management of Tropical Forests. 2017. Available online: https://asean.org/wp-content/uploads/2012/05/21.-ASEAN-CI-for-SFM.pdf (accessed on 15 May 2019).

126. UNFF. ASEAN inputs to the eleventh session of the United Nations Forum on Forest (UNFF) 2014. In Forests: Progress, Challenges and the Way Forward on the International Arrangement on Forests (IAF); ASEAN Secretariat: Jakarta, Indonesia, 2014.

127. Peters, B.G. Policy instruments and policy capacity. In Challenges to State Policy Capacity; Painter, M., Pierre, J., Eds.; Palgrave Macmillan: New York, NY, USA, 2005; pp. 73-91.

128. Salamon, L.M. Handbook of Policy Instruments; Oxford University Press: New York, NY, USA, 2001.

129. Oberthür, S.; Gehring, T. (Eds.) Institutional Interaction in Global Environmental Governance: Synergy and Conflict Among International and EU Policies; MIT Press: Cambridge, MA, USA, 2006.

130. Hafner, G. Pros and cons ensuing from fragmentation of international law. Mich. J. Int. L. 2003, $25,849$.

131. Briassoulis, H. Complex environment problems and the quest of policy integration. In Policy Integration for Complex Environmental Problems: The Example of Mediterranean Desertification; Briassoulis, H., Ed.; Ashgate: Aldershot, UK, 2005.

132. Böcher, M.; Töller, A.E. Conditions for the emergence of alternative environmental policy instruments. In Proceedings of the 2nd ECPR-Conference, Marburg, Germany, 18-21 September 2003.

133. Majone, G. Choice among policy instruments for pollution control. Policy Anal. 1976, 2, 589-613.

134. Thang, H.C. Managing regional expert pools through regional knowledge networks in ASEAN. In Seminar Proceedings ASEAN High-Level Seminar. Climate Change Adaptation and Mitigation: Towards a Cross-Sectoral Programme Approach in ASEAN; Van Wart, M., Goehler, D., Fawzia, F., Eds.; ASEAN: Jakarta, Indonesia, 2009.

135. Strutt, A.; Hertel, T.W.; Stone, S. Chapter 8 Exploring Poverty Impacts of ASEAN Trade Liberalization for Cambodia, Lao PDR, Thailand and Vietnam. In New Developments in Computable General Equilibrium Analysis for Trade Policy; Emerald Group Publishing Limited: Bingley, UK, 2010; pp. 217-245.

136. Solaymani, S.; Shokrinia, M. Economic and environmental effects of trade liberalization in Malaysia. J. Soc. Econ. Dev. 2016, 18, 101-120. [CrossRef]

137. Briones, R.M. Regional Cooperation for Food Security: The Case of Emergency Rice Reserves in the ASEAN Plus Three; ADB Sustainable Development Working Paper Series Publication Stock No. WPS114120; ADB: Metro Manila, Philippines, 2011.

(C) 2019 by the authors. Licensee MDPI, Basel, Switzerland. This article is an open access article distributed under the terms and conditions of the Creative Commons Attribution (CC BY) license (http://creativecommons.org/licenses/by/4.0/). 